\title{
IMPLEMENTASI MODEL PEMBELAJARAN KOOPERATIF TPS UNTUK MENINGKATKAN AKTIVITAS DAN HASIL BELAJAR PASSING SEPAKBOLA
}

\author{
Komang Budi Satriawan 1,* \\ 1 Universitas Pendidikan Ganesha
}

\begin{abstract}
Abstrak
Penelitian ini bertujuan untuk meningkatkan aktivitas dan hasil belajar keterampilan gerak passing permainan sepakbola menggunakan kaki bagian dalam. Penelitian ini merupakan

penelitian tindakan kelas, yaitu guru sebagai peneliti yang dilaksanakan dalam dua siklus, terdiri dari rencana tindakan, pelaksanaan tindakan, observasi dan evaluasi serta refleksi. Subjek penelitian ini adalah siswa kelas XI UPW B SMK Negeri 1 Singaraja, sejumlah 35 siswa. Data dianalisis menggunnakan statistik deskriptif. Hasil analisis data aktivitas belajar pada siklus I secara klasikal adalah $46 \%$ dan meningkat menjadi $86 \%$ pada siklus II, sedangkan hasil belajar aspek sikap secara klasikal pada siklus I adalah 63\% sedangkan pada siklus II adalah 91\%, pada aspek pengetahuan siklus I diperoleh secara klasikal 51\% dan meningkat menjadi $86 \%$ di siklus II. Aspek keterampilan siklus I diperoleh ketuntasan klasikal 66\% dan mingkat menjadi 89\% pada siklus II. Dapat disimpulkan bahwa aktivitas dan hasil belajar keterampilan gerak passing permainan sepakbola menggunakan kaki bagian dalam meningkat melalui implementasi model pembelajaran kooperatif tipe TPS. Disarankan kepada guru Penjasorkes agar mengimplementasikan model pembelajaran ini karena terbukti dapat meningkatkan aktivitas dan hasil belajar teknik passing sepakbola.
\end{abstract}

\author{
Kata-kata kunci: \\ model pembelajaran, \\ kooperatif,TPS, aktivitas \\ belajar, hasil belajar, \\ sepakbola
}

\section{PENDAHULUAN}

Sebuah bangsa akan menjadi bangsa yang maju dan mandiri jika didukung oleh generasi muda yang cerdas, mempunyai karakter yang kuat dan sehat secara jasmani. Ketiga faktor ini saling mendukung untuk menciptakan manusia seutuhnya. Mengacu pada pentingnya ketiga aspek tersebut, maka ketiga hal inilah yang mendasari pemerintah dalam menyusun sebuah sistem pendidikan nasional yang bertujuan untuk membentuk manusia Indonesia yang cerdas, sehat jasmani serta mempunyai karakter kebangsaan yang kuat. Hal ini tertera jelas pada Undang-Undang Sistem Pendidikan Nasional No. 20 tahun 2003 bab 2 Pasal 3 tentang Fungsi dan tujuan Pendidikan Nasional yang menyatakan bahwa "Pendidikan Nasional berfungsi untuk mengembangkan kemampuan dan membentuk watak serta peradaban bangsa yang bermartabat dalam rangka mencerdaskan kehidupan bangsa, bertujuan untuk mengembangkan potensi peserta didik agar menjadi manusia yang beriman dan bertakwa terhadap Tuhan Yang Maha Esa, berakhlak mulia, sehat, berilmu, kreatif, mandiri, dan menjadi warga negara yang demokratis serta bertanggung jawab".

Melalui pendidikan jasmani, olahraga dan kesehatan ini peserta didik akan dapat meningkatkan serta mengembangkan ketiga ranah yang ada yaitu sikap, pengetahuan dan keterampilan. Proses pembelajaran merupakan inti dari proses pendidikan secara keseluruhan dimana guru sebagai pemeran utamanya. Untuk mencapai tujuan tersebut, peran seorang guru sangatlah penting di dalam menentukan dan menerapkan model pembelajaran yang tepat, karena dengan model pembelajaran yang baik dan tepat, seorang guru dapat memacu keikut sertaan peserta didik secara aktif, kreatif dan inovatif dalam pembelajaran pendidikan jasmani, olahraga dan kesehatan.

Berdasarkan observasi awal yang peneliti lakukan di SMK Negeri 1 Singaraja pada materi keterampilan gerak passing permainan sepakbola menggunakan kaki bagian dalam, persentase aktivitas belajar peserta didik saat menerima pelajaran tergolong rendah. Peserta didik yang berada pada kategori sangat aktif tidak ada (0\%), yang berada pada kategori aktif sebanyak 8 orang (22\%), cukup aktif 
sebanyak 17 orang (49\%), kurang aktif 11 orang (29\%) dan peserta didik yang berada pada kategori sangat kurang aktif tidak ada (0\%). Sedangkan persentase hasil belajar keterampilan gerak passing permainan sepakbola menggunakan kaki bagian dalam peserta didik pada aspek pengetahuan diketahui peserta didik yang berada pada kategori tuntas sebanyak 9 orang (26\%), sedangkan peserta didik yang berada pada kategori tidak tuntas sebanyak 26 orang (74\%). Pada aspek sikap, peserta didik yang berada pada kategori baik sebanyak 18 orang (51\%), sedangkan peserta didik yang berada pada kategori cukup baik sebanyak 17 orang (49\%). Pada aspek keterampilan, peserta didik yang berada pada kategori tuntas sebanyak 17 orang (49\%), sedangkan peserta didik yang berada pada kategori tidak tuntas sebanyak 18 orang (51\%).

Hasil belajar dikatakan berhasil atau tuntas apabila berada pada rentang skor minimal

Dengan menganalisa data hasil belajar peserta didik secara keseluruhan terlihat hasil belajar masih tergolong kurang, karena belum memenuhi standar kriteria ketuntasan minimal (KKM) sekolah yang ditetapkan sebesar 76 dari nilai maksimal 100 .

Berdasarkan hasil refleksi awal, permasalahan yang dihadapi peserta didik dalam proses pembelajaran PJOK yaitu: (a) banyak teman lain yang mengganggu kosentrasi dan bercanda pada saat melakukan gerakan, (b) tidak ada kerjasama dengan teman dalam melakukan aktivitas gerak, (c) teman egois dan teman pintar tidak mau diajak berbagi, (d) proses pembelajaran kurang menarik dan selalu menoton sehingga cepa bosan dan jenuh, (e) Kurangnya pariasi model pembelajaran yang di gunakan.

Berdasarkan hal tersebut, peneliti mencoba mencari solusi dalam perbaikan aktivitas dan hasil pembelajaran khususnya pada PJOK pada materi sepak bola dengan menggunakan model pembelajaran kooperatif tipe TPS. TPS ini adalah merupakan jenis pembelajaran kooperatif yang di rancang untuk mempengaruhi pola interaksi siswa. Strategi TPS ini bekembang dari penelitian belajar kooperatif dan waktu tunggu. Dengan asumsi bahwa semua resitasi atau diskusi membutuhkan pengaturan untuk mengendalikan kelas secara keseluruhan, dan prosedur yang digunakan dalam TPS dapat memberi siswa lebih banyak waktu berpikir, untuk merespon dan saling membantu. Guru memperkirakan hanya melengkapi penyajian singkat atau siswa membaca tugas, atau situasi yang menjadi tanda tanya. Model kooperatif TPS ada beberapa langkah pembelajaran yang membuat siswa menjadi aktif yaitu:

1) Berpikir (Think), Guru menyajikan menyajikan suatu pertanyaan atau masalah yang dikaitkan dengan pembelajaran, dan meminta siswa menggunakan waktu beberapa menit untuk berpikir sendiri jawaban atau masalah, 2) Berpasangan (Pairing), guru meminta siswa untuk berpasangan dan mendiskusikan apa yang telah mereka peroleh. Interaksi selama waktu yang disediakan dapat menyatukan jawaban jika suatu pertanyaan yang diajukan atau menyatakan gagasan apabila suatu masalah khusus yang diidentifikasi. Secara normal guru memberi waktu tidak lebih dari 4 atau 5 menit untuk berpasangan. 3) Berbagi (sharing), pada langkah terakhir, guru meminta setiap pasangan untuk berbagi dengan keseluruhan kelas yang telah mereka bicarakan. Dengan demikian siswa akan termotivasi untuk lebih aktif, kreatif dan mandiri dalam proses pembelajaran.

Pemilihan tentang model pembeljaran TPS ini juga dikuatkan oleh hasil penelitian dari penelitipeneliti sebelumnya, diantaranya; 1) I komang Wiwik Sandita menemukan bahwa aktivitas dan hasil belajar Teknik passing bola sepak meningkat melalui penerapan model pembelajaran kooperatif tipe TPS pada siswa kelas X.1 SMA Negeri 1 Belah Batuh tahun pelajaran 2011/2012; 2) I Putu Junta Astu menemukan bahwa aktivitas dan hasi belajar lompat jauh meningkat melalui penerapan model pembelajaran kooperatif tipe TPS pada siswa kelas XD SMK Negeri 2 Abang tahun pelajaran 2011/2012; 3) Igusti Ngurah Manik Mahardika menemukan bahwa aktivitas dan hasi belajar Teknik lari jarak pendek (sprint) meningkat melalui penerapan model pembelajaran kooperatif tipe TPS pada siswa kelas X keuangan SMK PGRI 1 Singaraja tahun pelajaran 2011/2012;

Dengan demikian penerapanan model pembelajaran TPS diharapkan mampu meningkatkan aktivitas dan hasil belajar siswa kelas XI UPW B SMK Negeri 1 Singaraja tahun pelajaran 2017/2018.

\section{METODE PENELITIAN}

Jenis penelitian adalah pengolonggan penelitian berdasarkan pedoman dari segi mana penggolongan itu di tinjau (Kanca I Nyoman, 2010: 5). Jenis penelitian yang digunakan dalam penelitian ini adalah penelitian tindakan kelas (PTK) yang pelaksanaanya berupa penyajian atau latihan di lapangan. PTK merupakan suatu bentuk penelitian yang bersifat reflektif dengan melakukan tindakan-tindakan tertentu agar dapat memperbaiki dan atau meningkatkan praktek-praktek pembelajaran di kelas secara lebih profesional (Kanca I Nyoman, 2010: 108).

Ojan SN dalam (Kanca I Nyoman, 2010: 115) menyebutkan terdapat empat bentuk PTK, yaitu: (a) guru sebagai peneliti, (b) peneliti tindakan kolaboratif, (c) simultan-terintegrasi, dan (d) administrasi sosial eksperimental. 
Bentuk penelitian tindakan kelas yang memandang guru sebagai peneliti mempunyai ciri-ciri penting yaitu sangat berperannya guru itu sendiri dalam proses penelitian tindakan kelas (PTK). Dalam bentuk ini, tujuan utama penelitian tindakan kelas adalah untuk meningkatkan praktek-praktek pembelajaran di kelas, dimana guru terlibat secara penuh dalam proses perencanaan, aksi (tindakan) dan refleksi.

\section{ANALISIS DAN PEMBAHASAN}

Hasil analisis data aktivitas belajar pada siklus I diperoleh aktivitas belajar siswa secara klasikal sebesar 6,00. siswa yang aktif 16 orang (46\%) sedangkan siswa yang tidak aktif 19 orang (54\%). Adapun rinciannya sebagai berikut: siswa dengan kategori sangat aktif tidak ada, siswa dengan kategori aktif 16 orang dengan persentase 46\%, siswa dengan kategori cukup aktif 13 orang dengan persentase 37\% dan kategori kurang aktif 6 orang dengan persetase 17\%, serta kategori sangat kurang aktif tidak ada.

Tabel 1. Data Aktivitas Belajar Passing Sepak Bola pada Siklus I

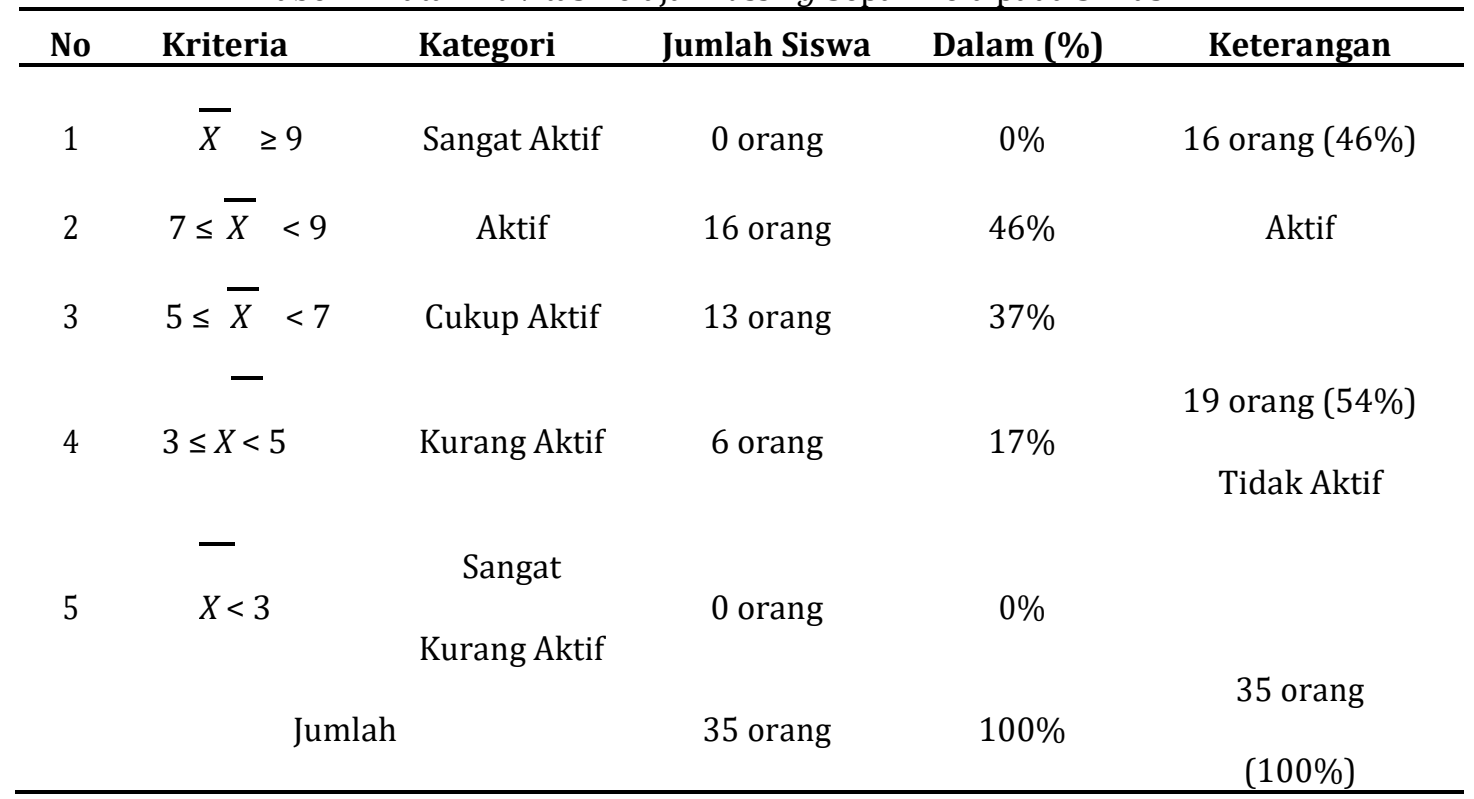

Penelitian hasil belajar siswa aspek sikap materi passing sepak bola pada siklus I bahwa persentase secara klasikal sebesar 63\%. Peserta didik yang berada pada kategori baik sebanyak 22 orang (63\%), sedangkan peserta didik yang berada pada kategori cukup baik sebanyak 13 orang (37\%).

Tabel 2. Aspek Sikap Passing Sepakbola pada Siklus I

\begin{tabular}{cccccc}
\hline No & Rentang & Jumlah & & & \\
& Skor & Siswa & Persentase & Kategori & Ket \\
\hline 1 & $86-100$ & - & - & Sangat Baik & 22 orang (63\%) \\
Tuntas
\end{tabular}

Penelitian hasil belajar siswa aspek pengetahuan materi passing sepak bola pada siklus I bahwa persentase secara klasikal sebesar 51\%. Peserta didik yang berada pada kategori tuntas sebanyak 18 orang (51\%), sedangkan peserta didik yang berada pada kategori tidak tuntas sebanyak 17 orang (49\%). 
Tabel 3. Aspek Pengetahuan Passing Sepakbola pada Siklus I

\begin{tabular}{cccccc}
\hline No & $\begin{array}{c}\text { Rentang } \\
\text { Skor }\end{array}$ & $\begin{array}{c}\text { Jumlah } \\
\text { Siswa }\end{array}$ & Persentase & Kategori & Keterangan \\
\hline 1 & $86-100$ & 5 & $14 \%$ & Sangat Baik & $\begin{array}{c}18 \text { orang } \\
(51 \%)\end{array}$ \\
2 & $76-85$ & 13 & $37 \%$ & Baik & Tuntas \\
3 & $66-75$ & 9 & $26 \%$ & Cukup Baik & 17 orang \\
& & & & Kurang Baik & $(49 \%)$ \\
4 & $0-65$ & 8 & $23 \%$ & & Tidak Tuntas \\
\hline
\end{tabular}

Penelitian hasil belajar siswa aspek Keterampilan materi passing sepak bola pada siklus I bahwa persentase secara klasikal sebesar 66\%. Peserta didik yang berada pada kategori tuntas sebanyak 23 orang (66\%), sedangkan peserta didik yang berada pada kategori tidak tuntas sebanyak 12 orang (34\%).

Tabel 4. Aspek Keterampilan Passing Sepakbola pada Siklus I

\begin{tabular}{|c|c|c|c|c|c|}
\hline No & $\begin{array}{c}\text { Rentang } \\
\text { Skor } \\
\end{array}$ & $\begin{array}{c}\text { Jumlah } \\
\text { Siswa } \\
\end{array}$ & Persentase & Kategori & Keterangan \\
\hline 1 & $86-100$ & 9 & $28 \%$ & Sangat & 23 orang \\
\hline & & & & Baik & $(66 \%)$ \\
\hline 2 & $76-85$ & 14 & $39 \%$ & $\begin{array}{c}\text { Baik } \\
\text { Cukup }\end{array}$ & $\begin{array}{l}\text { Tuntas } \\
12 \text { orang }\end{array}$ \\
\hline 3 & $66-75$ & 7 & $19 \%$ & & \\
\hline 4 & $0-65$ & 5 & $14 \%$ & $\begin{array}{c}\text { Baik } \\
\text { Kurang }\end{array}$ & $\begin{array}{l}(34 \%) \\
\text { Tidak }\end{array}$ \\
\hline & Jumlah & 36 & $100 \%$ & Baik & Tuntas \\
\hline
\end{tabular}

Hasil analisis data aktivitas belajar pada siklus II diperoleh aktifitas belajar siswa secara klasikal sebesar 72 yang tergolong aktif. Adapun data aktifitas belajar siswa secara individu yaitu sebagai berikut, peserta didik yang berada pada katagori sangat aktif sebanyak 0\% (tidak ada), aktif sebanyak 30 orang (86\%), cukup aktif sebanyak 5 orang (14\%), kurang aktif $0 \%$ (tidak ada) dan sangat kurang aktif $0 \%$ (tidak ada).

Tabel 5. Data Aktivitas Belajar Passing Bola Basket pada Siklus II

\begin{tabular}{|c|c|c|c|c|c|c|}
\hline No & $\begin{array}{c}\text { Nilai } \\
\text { Aktivitas }\end{array}$ & $\begin{array}{c}\text { Jumlah } \\
\text { Peserta } \\
\text { didik }\end{array}$ & $\begin{array}{c}\text { Persentase } \\
(\%)\end{array}$ & Kategori & Ket. & $\begin{array}{c}\text { Persentase } \\
(\%)\end{array}$ \\
\hline 1 & $\bar{X} \geq 9$ & - & - & Sangat aktif & & 30 orang \\
\hline 2 & $7-8,9$ & 30 & $86 \%$ & Aktif & Aktif & $(86 \%)$ \\
\hline 3 & $5-6,9$ & 5 & $14 \%$ & Cukup Aktif & & \\
\hline 4 & $3-4,9$ & - & - & $\begin{array}{l}\text { Kurang Aktif } \\
\text { Sangat Kurang }\end{array}$ & $\begin{array}{l}\text { Tidak } \\
\text { Aktif }\end{array}$ & 5 orang \\
\hline 5 & $0-2,9$ & - & - & Aktif & & \\
\hline
\end{tabular}


Penelitian hasil belajar siswa aspek sikap materi passing sepak bola pada siklus II bahwa persentase secara klasikal sebesar 91\%. Peserta didik yang berada pada kategori baik sebanyak 32 orang (91\%), sedangkan peserta didik yang berada pada kategori cukup baik sebanyak 3 orang (9\%).

Tabel 6. Aspek Sikap Passing Sepakbola pada Siklus II

\begin{tabular}{cccccc}
\hline No & Rentang & Jumlah & & Kategori & Keterangan \\
& Skor & Siswa & Persentase & & \\
\hline 1 & $86-100$ & - & - & Sangat Baik & 32 orang \\
& & & & & Baik \\
2 & $76-85$ & 32 & $91 \%$ & Cukup Baik & 3 orang (9\%) \\
3 & $66-75$ & 3 & - & Kurang Baik & Tidak Tuntas \\
4 & $0-65$ & - & $100 \%$ & & \\
\hline
\end{tabular}

Penelitian hasil belajar siswa aspek pengetahuan materi passing sepak bola pada siklus II bahwa persentase secara klasikal sebesar 86\%. Peserta didik yang berada pada kategori tuntas sebanyak 30 orang (86\%), sedangkan peserta didik yang berada pada kategori tidak tuntas sebanyak 5 orang (14\%).

Tabel 7. Aspek Pengetahuan Passing Sepakbola pada Siklus II

\begin{tabular}{|c|c|c|c|c|c|}
\hline No & $\begin{array}{c}\text { Rentang } \\
\text { Skor }\end{array}$ & $\begin{array}{c}\text { Jumlah } \\
\text { Siswa }\end{array}$ & Persentase & Kategori & Keterangan \\
\hline 1 & $86-100$ & 5 & $14 \%$ & $\begin{array}{c}\text { Sangat Baik } \\
\text { Baik }\end{array}$ & $\begin{array}{c}18 \text { orang } \\
(51 \%)\end{array}$ \\
\hline 2 & $76-85$ & 13 & $37 \%$ & & Tuntas \\
\hline 3 & $66-75$ & 9 & $26 \%$ & $\begin{array}{c}\text { Cukup Baik } \\
\text { Kurang Baik }\end{array}$ & $\begin{array}{c}17 \text { orang } \\
(49 \%)\end{array}$ \\
\hline 4 & $0-65$ & 8 & $23 \%$ & & \\
\hline & Jumlah & 35 & $100 \%$ & & Tidak Tuntas \\
\hline
\end{tabular}

Penelitian hasil belajar siswa aspek Keterampilan materi passing sepak bola pada siklus II bahwa persentase secara klasikal sebesar 89\%. Peserta didik yang berada pada kategori tuntas sebanyak 31 orang (89\%), sedangkan peserta didik yang berada pada kategori tidak tuntas sebanyak 4 orang $(11 \%)$.

Tabel 8. Aspek Keterampilan Passing Sepakbola pada Siklus II

\begin{tabular}{cccccc}
\hline No & Rentang & Jumlah & & & \\
& Skor & Siswa & Persentase & Kategori & Keterangan \\
\hline 1 & $86-100$ & 11 & $32 \%$ & Sangat Baik & $\begin{array}{c}31 \text { orang } \\
(89 \%)\end{array}$ \\
& & & & & Baik \\
2 & $76-85$ & 20 & $57 \%$ & & Tuntas \\
3 & $66-75$ & 3 & $8 \%$ & Cukup Baik & 4 orang (11\%) \\
4 & $0-65$ & 1 & $3 \%$ & Kurang Baik & Tidak Tuntas \\
& Jumlah & 35 & $100 \%$ & & \\
\hline
\end{tabular}


Berdasarkan informasi yang diperoleh terdapat beberapa masalah yang terjadi pada siswa kelas XI UPW B SMK Negeri 1 Singaraja tahun pelajaran 2017/2018 mengenai aktivitas dan hasil belajar passing sepak bola. Oleh karena itu peneliti melakukan penelitian dengan mengimplementasikan model pembelajaran kooperatif tipe TPS. Berdasarkan hasil penelitian yang telah dilaksanakan dua siklus dengan masing masing siklus 2 kali pertemuan, menunjukkan terjadi peningkatan aktivitas dan hasil belajar siswa dengan implementasi model pembelajaran kooperatif tipe TPS.

Dengan mengimplementasikan model pembelajaran kooperatif tipe TPS aktivitas dan hasil belajar menjadi lebih baik dari observasi awal. Pada siklus I aktivitas belajar tergolong kategori aktif. Sedangkan pada siklus II aktivitas belajar tergolong dalam aktif.

Tabel 9. Peningkatan Aktivitas Belajar Passing Bola Basket Per Tahap

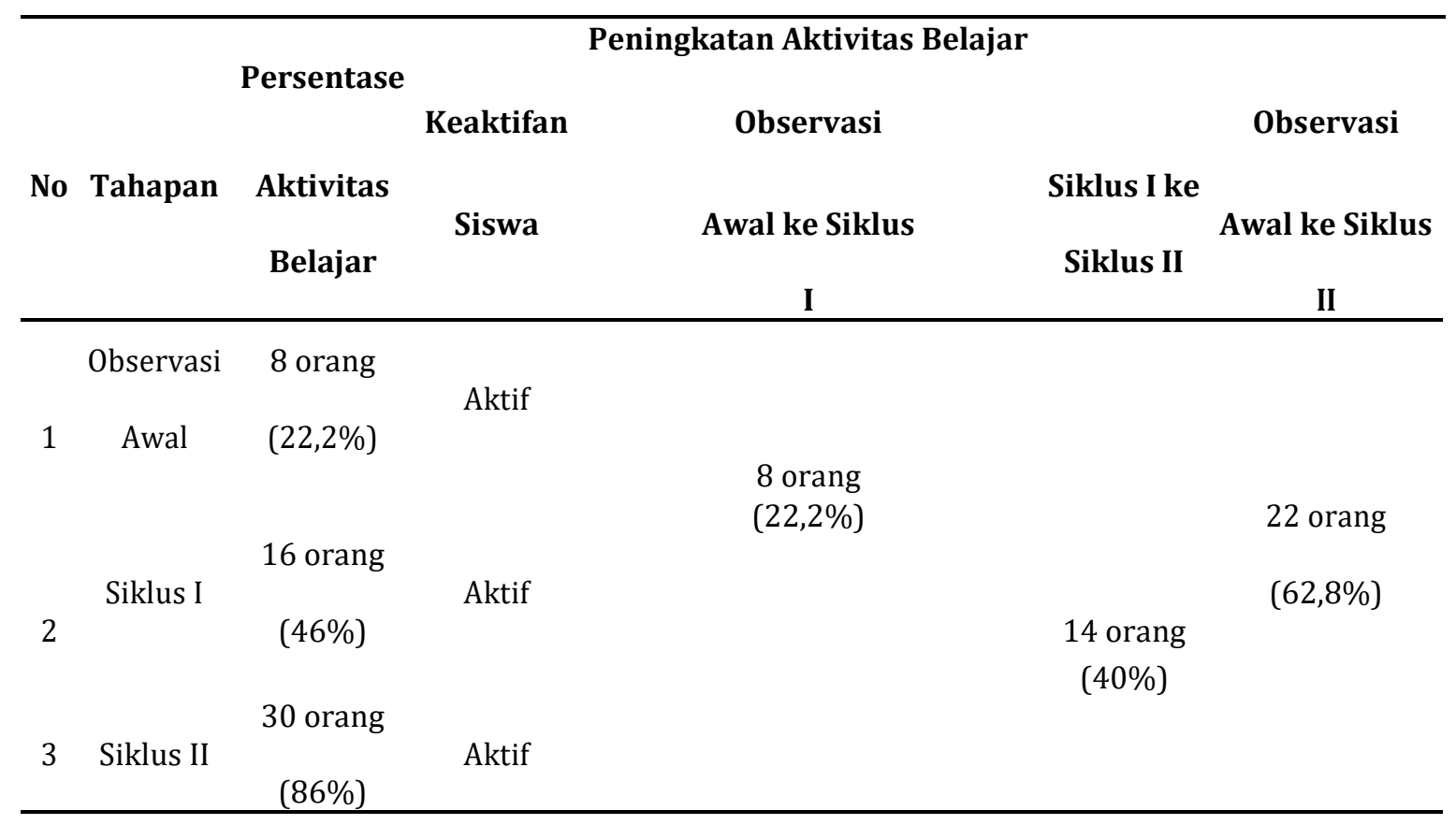

Sedangkan untuk hasil belajar pada siklus I ke siklus II terjadi peningkatan sehingga siswa yang tuntas. Pada siklus II ini peneliti memberikan tindakan-tindakan TPS dengan melihat kelemahankelemahan pada siklus I.

Tabel10. Peningkatan Hasil Belajar Passing Bola Basket Per Tahap

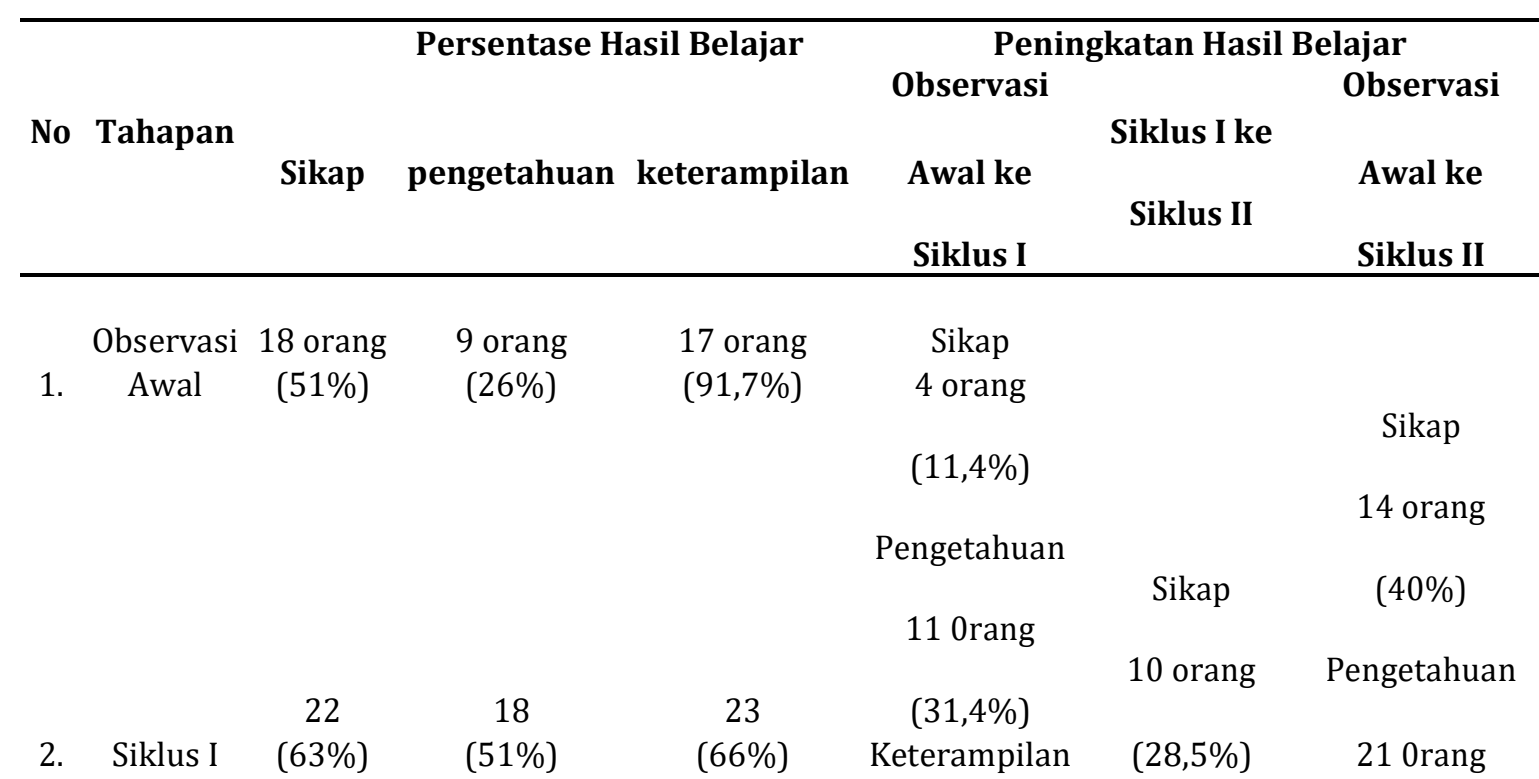




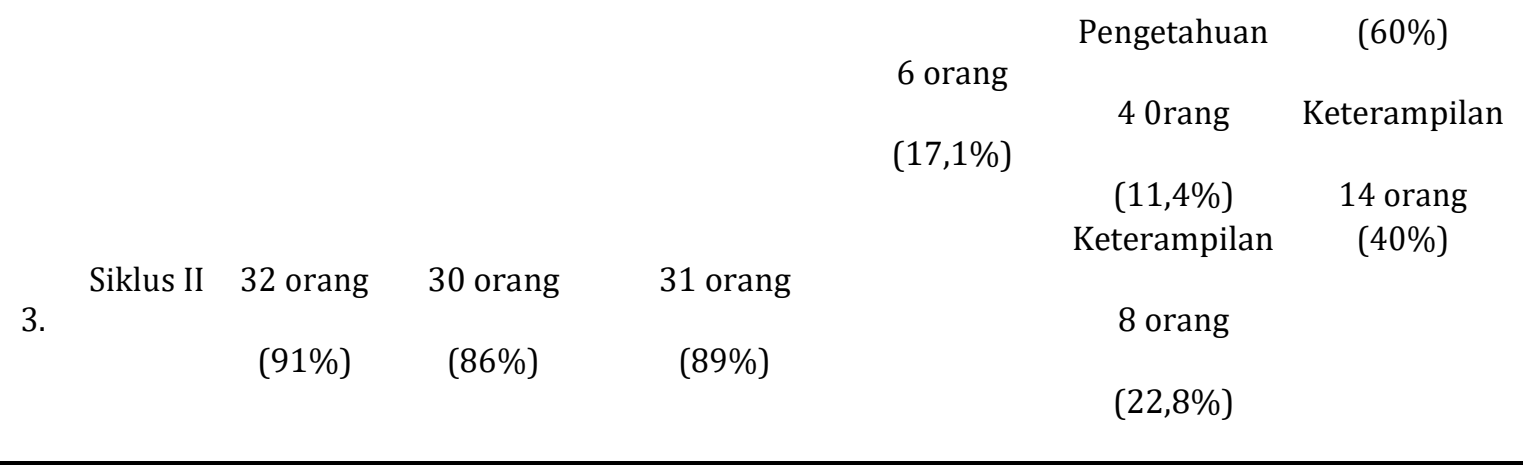

Penelitian ini diawali dengan melakukan obeservasi awal yang dilakukan oleh peneliti pada siswa kelas XI UPW B SMK Negeri 1 Singaraja saat melaksanakan pengajaran PJOK berkaitan dengan PPL-PPG di sekolah tersebut. Peserta didik kelas XI UPW B SMK Negeri 1 Singaraja mengalami masalah dalam hasil belajar PJOK khususnya pada materi keterampilan gerak passing permainan sepakbola menggunakan kaki bagian dalam. Hal ini dapat dilihat dari nilai PJOK yang dicapai oleh peserta didik belum mencapai standar yang ditetapkan. Persentase ketuntasan hasil belajar peserta didik untuk kelas XI di SMK Negeri 1 Singaraja yaitu 76.

Berdasarkan hasil refleksi aktivitas belajar pada siklus I diketahui bahwa aktivitas belajar keterampilan gerak passing permainan sepakbola menggunakan kaki bagian dalam telah mengalami peningkatan sebesar $46 \%$ (16 orang) menjadi aktif, dimana pada saat observasi awal peserta didik yang berada pada kriteria aktif sebesar $22,2 \%$ (8 orang). Peneliti mengkaji serta mempertimbangkan dampak dari tindakan yang diberikan dan melakukan perbaikan atas kekurangan-kekurangan dan hambatan yang ditemui pada siklus I. Permasalahan yang ditemukan adalah: (1) Siswa belum mengamati guru/model dalam mendemonstrasikan keterampilan gerak passing permainan sepakbola menggunakan kaki bagian dalam. (2) Siswa belum berani mengemukakan pendapat dan memberikan saran dalam diskusi. (3) Siswa belum begitu berani dalam melakukan keterampilan gerak passing permainan sepakbola menggunakan kaki bagian dalam. (4) Siswa belum percaya diri dalam menghadapi dan memecahkan masalah

Tindakan-tindakan yang dilakukan untuk mengatasi permasalahan tersebut adalah : (1) memotivasi siswa lagi agar lebih bersemangat dan aktif lagi dalam mengikuti pembelajaran, (2) memperbanyak jumlah kelompok, memperkecil jumlah anggota dalam satu kelompok sehingga diharapkan nantinya kesempatan belajar siswa lebih banyak.

Setelah diberi tindakan kembali pada siklus II, diketahui bahwa aktivitas belajar keterampilan gerak passing permainan sepakbola menggunakan kaki bagian dalam sudah mengalami peningkatan sebesar 86\% (30 orang) menjadi aktif, dimana pada tindakan siklus I hanya mengalami peningkatan sebesar 46\% (16 orang). Karena keterbatasan waktu sehingga penelitian hanya sampai pada siklus II dan hasil yang diperoleh direkomendasikan sebagai laporan dan kepada guru penjasorkes yang bersangkutan.

Setelah diberi tindakan pada siklus I, berdasarkan hasil observasi dan evaluasi untuk hasil belajar keterampilan gerak passing permainan sepakbola menggunakan kaki bagian dalam pada aspek sikap sudah mengalami peningkatan sebesar 63\% (22 orang) berada pada kategori aktif, pada aspek pengetahuan sebesar 51\% (18 orang) berada pada kategori tuntas dan pada aspek keterampilan sebesar $66 \%$ (23 orang) berada pada kategori tuntas namun untuk ketuntasan hasil belajar siswa secara klasikal belum memenuhi kriteria ketuntasan minimal yang ditentukan yaitu sebesar 76\%. Masalah yang menyebabkan ketidak tuntasan tersebut adalah: (1) Sikap yang ditunjukkan siswa dalam mengikuti pembelajaran masih tergolong cukup, (2) Kurangnya penguasaan keterampilan gerak passing permainan sepakbola menggunakan kaki bagian dalam.

Tindakan yang dilakukan untuk mengatasi masalah tersebut adalah dengan (1) lebih menekankan kepada siswa tentang materi keterampilan gerak passing permainan sepakbola menggunakan kaki bagian dalam dari sikap awal, sikap pelaksanaan dan sikap akhir, (2) memperbanyak jumlah kelompok, memperkecil jumlah anggota dalam satu kelompok sehingga kesempatan belajar siswa lebih banyak dan diharapkan hasil belajar dapat meningkat.

Setelah diberi tindakan pada siklus II, berdasarkan hasil observasi dan evaluasi untuk hasil belajar keterampilan gerak passing permainan sepakbola menggunakan kaki bagian dalam pada aspek sikap sudah mengalami peningkatan sebesar 91\% (32 orang) berada pada kategori aktif, pada aspek pengetahuan sebesar 86\% (30 orang) berada pada kategori tuntas dan pada aspek keterampilan sebesar $89 \%$ (31 orang) berada pada kategori tuntas. 
Pada siklus II hasil belajar sudah dikatakan berhasil karena telah mencapai kriteria ketuntasan minimal yang ditetapkan di SMK Negeri 1 Singaraja yaitu sebesar 76\%. Karena ketuntasan hasil belajar siswa sudah mencapai hasil yang maksimal, maka penelitian tidak dilanjutkan lagi dan hasil yang diperoleh direkomendasikan sebagai bahan laporan serta kepada guru penjasorkes yang bersangkutan.

Hasil penelitian ini sejalan dengan hasil penelitian yang relevan dan juga dikuatkan oleh beberapa hasil penelitian dari peneliti-peneliti sebelumnya, antara lain: I Komang Wiwik Sandita menemukan bahwa aktivitas dan hasil belajar Teknik passing bola sepak meningkat melalui

penerapan model pembelajaran kooperatif tipe TPS pada siswa kelas X.1 SMA Negeri 1 Belah Batuh tahun pelajaran 2011/2012" menjelaskan bahwa implementasi model pembelajaran kooperatif tipe TPS sangat mempengaruhi peningkatan aktivitas dan hasil belajar lompat jauh siswa. Hal tersebut dipengaruhi oleh peningkatan aktivitas belajar siswa dengan analisis data aktivitas belajar secara klasikal siklus I adalah 77,12\% (aktif) meningkat menjadi 81,62\% (sangat aktif) pada siklus II, peningkatan aktivitas belajar siswa berpengaruh pada hasil belajarnya. Melalui hal tersebut penulis mengkonversikan penerapan model pembelajaran kooperatif tipe TPS dapat meningkatkan aktivitas dan hasil belajar.

Berdasarkan hasil penelitian yang telah peneliti lakukan serta teori-teori pendukung hasil penelitian relevan yang telah dipaparkan di atas, dapat disimpulkan bahwa implementasi model pembelajaran kooperatif tipe TPS dapat meningkatkan aktivitas dan hasil belajar keterampilan gerak passing permainan sepakbola menggunakan kaki bagian dalam pada siswa kelas XI UPW B SMK Negeri 1 Singaraja tahun pelajaran 2017/2018.

Penelitian yang sudah dilaksanakan ini tidaklah selalu berjalan dengan lancar sesuai dengan yang diharapkan dan yang sudah direncanakan. Karena ada kendala-kendala yang dihadapi peneliti dalam menjalankan penelitian ini. Adapun kendala-kendala yang dihadapi adalah: (1) fasilitas yang dimiliki sekolah sangat kurang pelaksanaan pembelajaran menjadi kurang efektif, (2) Respon siswa untuk memahami materi tergolong lambat, (3) Siswa juga terbilang sedikit manja.

Dari kendala-kendala yang dihadapi tersebut maka yang dilakukan peneliti untuk memecahkannya sehingga penelitian yang dilakukan dapat berjalan dengan lancar diantaranya adalah: (1) menggunakan sarana dan prasarana yang sudah ada dan untuk kekurangannya dipinjamkan di tempat lain dan peneliti memodifikasi sarana yang dipergunakan. (2) menjelaskan kembali secara berulang-ulang materi yang belum dimengerti agar siswa lebih memahami materi yang dipelajari. (3) memberikan arahan dan motivasi tambahan.

\section{KESIMPULAN}

Berdasarkan hasil analisis data dan pembahasan, dapat ditarik kesimpulan yaitu hasil belajar PJOK meningkat melalui penerapan model pembelajaran pembelajaran kooperatif tipe TPS pada peserta didik kelas XI UPW B SMK Negeri 1 Singaraja tahun ajaran 2017/2018. Hal ini dapat di lihat dari persentase ketuntasan aktivitas belajar dari observasi awal sebesar 5,5 meningkat pada siklus I sebesar 6,00 yang berada pada kategori cukup aktif dan kembali mengalami peningkatan pada siklus II yaitu sebesar 7,2 yang berada pada kategori aktif.

Berdasarkan hasil observasi dan evaluasi hasil belajar siklus I keterampilan gerak passing permainan sepakbola menggunakan kaki bagian dalam pada aspek sikap sudah mengalami peningkatan sebesar 63\% (22 orang) berada pada kategori aktif, pada aspek pengetahuan sebesar 51\% (18 orang) berada pada kategori tuntas dan pada aspek keterampilan sebesar 66\% (23 orang) berada pada kategori tuntas namun untuk ketuntasan hasil belajar siswa secara klasikal belum memenuhi kriteria ketuntasan minimal yang ditentukan yaitu sebesar $76 \%$. Setelah diberi tindakan pada siklus II, berdasarkan hasil observasi dan evaluasi untuk hasil belajar keterampilan gerak passing permainan sepakbola menggunakan kaki bagian dalam pada aspek sikap sudah mengalami peningkatan sebesar 91\% (32 orang) berada pada kategori aktif, pada aspek pengetahuan sebesar $86 \%$ (30 orang) berada pada kategori tuntas dan pada aspek keterampilan sebesar 89\% (31 orang) berada pada kategori tuntas. Pada siklus II hasil belajar sudah dikatakan berhasil karena telah mencapai kriteria ketuntasan minimal yang ditetapkan di SMK Negeri 1 Singaraja yaitu sebesar 76\%.

\section{DAFTAR PUSTAKA}

Arikunto, Suhadjono, dan Supardi. 2008. Penelitian Tindakan Kelas. Jakarta: PT Bumi Aksara.

Dimyati dan Mudjiono. 2006. Belajar dan Pembelajaran. Jakarta: RinekaCipta.

Hamalik, Oemar. 2008. Kurikulum dan Pembelajaran. Jakarta: PT Bumi Aksara.

Satriawan (2017).

Jurnal Penelitian dan Pengembangan Pendidikan. Vol. 1 (2) pp. 40-48 
I Komang Wiwik Sandita. 2012. penerapan model pembelajaran kooperatif tipe TPS pada siswa kelas X.1 SMA Negeri 1 Belah Batuh tahun pelajaran 2011/2012

I Putu Junta Astu. 2012. penerapan model pembelajaran kooperatif tipe TPS pada siswa kelas VIID SMP Negeri 2 Abang tahun pelajaran 2011/2012

Kanca, I Nyoman. 2010. Metode Penelitian Pengajaran Pendidikan Jasmani dan Olahraga. Singaraja: Universitas Pendidikan Ganesha.

Kementerian Pendidikan dan Kebudayaan. 2014. Buku Guru Pendidikan Jasmani, Olahraga, dan Kesehatan SMA/MA,SMK/MA Kelas X. Cetakan Ke-1. Jakarta: Kementerian Pendidikan dan Kebudayaan

Nurhadi, dkk. 2004.Pembelajaran Kontekstual dan Penerapannya dalam KBK. Malang: Universitas Negeri Malang.

Nurkancana dan Sunartana. 1992.Evaluasi Hasil Belajar. Surabaya: Usaha Nasional.

Slavin, E Roberto. 2008 . Pembelajaran Kooperatif : Teori, riset dan Praktek Bandung : Nusa Media.

Sukardjo, S. dan Nurhasan.1992. Evaluasi Pengajaran Pendidikan Jasamani dan Kesehatan. Surabaya : Departemen Pendidikan dan Kebudayaan.

Trianto. 2007. Model-Model Pembelajaran Inovatif. Jakarta: Prestasi Pustaka Publisher.

Undiksha, 2011. Pedoman Penulisan Skripsi dan Tugas Akhir. Singaraja: Departemen Pendidikan Nasional Universitas Pendidikan Ganesha. 